\title{
Editorial
}

\section{AVANCES Y RESISTENCIAS EN EL LARGO CAMINO HACIA LA IGUALDAD DE LA MUJER}

Forzar hipótesis es una práctica buena tanto para la docencia como para la investigación. En temas trabajados y novedosos, forzar hipótesis nos sitúa en otro plano y proporciona nuevas vías. Si preguntara por ejemplo si es posible el feminismo en Marruecos, o preguntara por las cuotas que favorezcan a la mujer, probablemente se plantearía un debate antagónico y encendido. Esas preguntas tienen una parte de "forzar hipótesis" y así es como se podría por tanto iniciar este tema también en una editorial.

En el largo camino hacia la igualdad hay muchas resistencias pendientes, ámbitos y comportamientos que superar. Aunque las mujeres han hecho grandes avances disminuyendo la desigualdad, se sigue confirmando en la actualidad la persistencia de discriminaciones. Estamos aún entre la reproducción de la desigualdad y la resistencia a los cambios.

Además de la diferencia en el acceso a empleos, cuestiones de tipo político, aspectos en la salud de la mujer, el grado y espacio de representación en distintos órdenes; son evidentes la existencia de la división sexual del trabajo (sueldos más precarios, profesiones feminizadas, carreras de estudio no técnicas o científicas) y el grado de poder según la esfera privada y doméstica o la pública. El sexismo más sutil, encubierto, que pasa por las formas más inadvertidas que incluye un tratamiento desigual; la cosificación, la mercantilización del cuerpo; el lenguaje, las creencias negacionistas de la desigualdad; son diferentes versiones de las limitaciones para la mujer, que en muchos países deben superarse a su propio ritmo. El sujeto, marca su ritmo en su contexto.

En cuanto a la investigación, es de absoluto interés observar las circunstancias que caracterizan el momento actual de superación de la desigualdad entre hombres y mujeres, la resistencia a los cambios y los cambios en sí que se presentan. Parece que el siglo XXI ha sido crucial a la hora de visibilizar una diferencia tradicionalmente camuflada. Y ese gran progreso de la visibilización nos ha llevado a concluir, quizá apresuradamente que hemos superado la desigualdad, que no existen retos ni hándicaps que superar. Las denuncias, principalmente por violencia de género se han hecho visibles con el "Metoo" o con el grito de guerra "un violador en tu camino", pero podrían ponerse otros ejemplos. ¿Qué se ha producido? Por un lado, se ha producido un cambio sistémico. Sara Khan, politóloga de la Universidad de Yale nos habla del "conocimiento común" Un cambio social se produce a partir de las creencias y valores de los demás y no de lo que uno cree. Tiene que ser patente (mostrado), que las ideas de los demás han cambiado o producir un consenso a escala más amplia. Para un "conocimiento común" se precisan "rituales públicos", expresar experiencias compartidas que tienen la capacidad de mostrar de forma pública y evidente la idea que tenemos sobre el hecho a todos los demás. En ese sentido, se ha producido un "conocimiento 
común" mediante o desde el "Metoo" o del grito de guerra, no exento de debates dentro del propio ámbito feminista.

La impunidad y la "cultura del acoso" a mayor escala, también marcan los cambios. Si no se consigue castigar a los perpetradores, se corre el riesgo de transmitir el mensaje de que aunque miles de mujeres exijan un cambio, al no haber medidas en la clase dirigente para ejecutarlo, no se logra. A esto se añade que las mujeres menos privilegiadas pueden ser más vulnerables y su visibilidad no acapara espacios. Es evidente por tanto la importancia de la adopción de medidas y la investigación para llevarlo a cabo.

Estamos aún entre la reproducción de la desigualdad y la resistencia a los cambios. Pero este intento de superar la desigualdad se ha experimentado con enfoques distintos: se ha desplazado la performance de mostrarse desnuda, cortar sujetadores, gritar en debates políticos, por la de la sororidad. Celia Amorós (2000) en la presentación del libro Feminismo y Filosofía dice "No puede decirse, pues, que las feministas se hayan comportado como pacifistas en todas las circunstancias: consideraciones tácticas diversas las han llevado a adoptar actitudes asimismo diversas." Pero ha habido un cambio inteligente en la acción. Y es más inclusiva. No hay feministas de primera o de segunda, de España o de Marruecos. Gortz, basándose en el trabajo de Bell en el magnífico libro: el advenimiento de la sociedad postindustrial, habla de la existencia de una nueva no-clase que no se define ya por su posición en el proceso de producción. Gortz y Touraine, hacen un esfuerzo teórico por comprender los nuevos fenómenos sociales, identificando un nuevo sujeto de acción y un nuevo cambio. La respuesta juvenil, ecologista, la participación ciudadana en reivindicaciones, etc., ofrecen una nueva forma de pensar y vivir la vida que se traslada a otras esferas.

Aunque la obra de Bell se escribe en el 73 y distintos teóricos desarrollan durante los 80 estas teorías, la irrupción clara de este nuevo sujeto, se está viendo durante el siglo XXI. El movimiento de acción es el feminista. Nuevos sujetos de cambio, surgen a la vez con puntos de contacto. Habría que considerar remotos orígenes en su desarrollo y explicar adecuadamente las transformaciones. Solo mencionaré que el movimiento rescata la tradición anarquista del siglo XIX, reactualiza el movimiento hippie y comunitario de los sesenta, se vincula con otros movimientos como el pacifismo y el ecologismo (ecofeminismo). A finales del XX y principios del XXI se diferencia entre la agenda institucional y la emancipadora, otras dos realidades para el cambio.

Así que puntos en común, transformación inteligente, y vinculación con otros movimientos. Esto hace pensar no en cambios en la sociedad sino en cambios en el feminismo.

La meta más evidente es el cambio más esperanzador: el de la vida cotidiana, la esfera doméstica y el ámbito educativo. Pero también son los más difíciles.

De la educación y la vida cotidiana hablan las siguientes páginas. Sin duda este es un hermoso ejemplar para el estudio del cambio y un gran proyecto coordinado por la doctora Carmen Vázquez Domínguez y el periodista y sociólogo Manuel Domínguez Moreno bajo el título: 
Mujer y educación. Un largo camino hacia la igualdad. Lo es porque utiliza los enfoques histórico, antropológico y sociológico. No existe triunfo mayo que poder, y saber combinarlos. Estas páginas muestran como académicas reconocidas se entrecruzan en su estudio sobre la desigualdad de hombres y mujeres con otras académicas no tan conocidas. Las contribuciones al presente ejemplar son todas brillantes, y entusiastas. Esas son las palabras que las definen y las cualidades que afronta el cambio del que hablo. Solo puede afrontar la transformación de los cambios pendientes un feminismo inteligente, que incluya diferentes versiones de sí mismo y por tanto que sea inclusivo. Sororidad es más que una palabra y de forma muy simbólica nos muestra los retos que tienen las mujeres empezando por la educación. Nos muestra un largo camino hacia la igualdad.

En nombre de quienes han participado en este magnífico ejemplar, deseamos que disfruten de su lectura y que pueda abrir nuevas visiones y espacios de trabajo e investigación. 